\title{
Alkalinized sewage sludge application improves fertility of acid soils
}

\author{
Aplicação de lodo de esgoto alcalinizado melhora a fertilidade de solos ácidos
}

\author{
Julierme Zimmer Barbosa', Giovana Clarice Poggere², Maristela Dalpisol' ${ }^{1}$, Beatriz Monte Serrat ${ }^{1}$, \\ Simone Bittencourt ${ }^{3}$, Antonio Carlos Vargas Motta ${ }^{1 *}$
}

\author{
1Universidade Federal do Paraná/UFPR, Curitiba, PR, Brasil \\ 2Universidade Federal de Lavras/UFLA, Departamento de Ciência do Solo/DCS, Lavras, MG, Brasil \\ ${ }^{3}$ Companhia de Saneamento do Paraná, Curitiba, PR, Brasil \\ *Corresponding author: mottaufpr@gmail.com \\ Received in March 12, 2017 and approved in July 18, 2017
}

\begin{abstract}
Although it is known that alkalinized sewage sludge raises the $\mathrm{pH}$ of acid soils, there is limited knowledge regarding its effects on other soil fertility indicators, such as $\mathrm{P}$ and $\mathrm{K}$ availability and soil organic $\mathrm{C}$ content. Thus, the goal of this study was to evaluate how the application of alkalinized sewage sludge affects the fertility of acid soil. Twenty sewage treatment plants were selected throughout Paraná State (Brazil), and samples of alkalinized sewage sludge and samples of the most representative agricultural soil of the region were collected (covering soils with medium, clayey or very clayey texture). Each soil was incubated for 60 days with doses of sewage sludge $\left(0,10,20,40\right.$, and $\left.80 \mathrm{Mg} \mathrm{ha}^{-1}\right)$ from its region and equivalent doses of limestone. The alkalinized sewage sludge was superior to limestone in the correction of soil acidity $\left(\mathrm{pH}, \mathrm{Al}^{3+}\right.$, and $\left.\mathrm{H}+\mathrm{Al}^{3^{+}}\right)$and $\mathrm{P}$ and $\mathrm{Ca}^{2+}$ availability. The sludge also increased $\mathrm{Mg}^{2+}$ availability in all soils, $\mathrm{K}^{+}$in seven soils and organic $\mathrm{C}$ in three soils. The very clayey soils (higher buffering capacity) supported higher sludge doses than did clayey and medium texture soils. The alkalinized sewage sludge application in acid soils proved to be an interesting alternative to recycling this type of waste, because it improved soil fertility and could reduce costs associated with soil management and crop fertilization.
\end{abstract}

Index terms: Sanitation waste; liming; phosphorus recovery; nutrient source; organic matter.

\begin{abstract}
RESUMO
Embora seja conhecido a capacidade do lodo de esgoto alcalinizado em elevar o pH de solos ácidos, tem-se um limitado conhecimento sobre o efeito em outros indicadores da fertilidade do solo, como disponibilidade de P e K e, teor de C orgânico no solo. Assim, o objetivo do estudo foi avaliar como a aplicação de lodo de esgoto alcalinizado afeta a fertilidade de solos ácidos. Foram selecionadas vinte estações de tratamento de esgoto ao longo do Paraná (Brasil), onde foram coletadas amostras de lodo de esgoto alcalinizado e amostras do solo agrícola mais representativo da região (abrangendo solos com textura média, argilosa ou muito argilosa). Cada solo foi incubado por 60 dias com doses de lodo de esgoto $\left(0,10,20\right.$, 40, e $\left.80 \mathrm{Mg} \mathrm{ha}^{-1}\right)$ da sua região e com doses equivalentes de calcário. O lodo de esgoto alcalinizado foi superior ao calcário na correção da acidez do solo $(\mathrm{pH}$, $\mathrm{Al}^{3+}$ e H+Al ${ }^{3+}$ ) e na elevação da disponibilidade $\mathrm{P}$ e $\mathrm{Ca}^{2+}$. O lodo também aumentou a disponibilidade de $\mathrm{Mg}^{2+}$ em todos os solos, $\mathrm{K}^{+}$em sete solos e C orgânico em três solos. Os solos muito argilosos (alta poder tampão) suportam maior dose de lodo em comparação aos solos de textura argilosa e média. A aplicação de lodo de esgoto alcalinizado em solos ácidos demonstrou ser uma interessante alternativa para reciclar esse tipo de resíduo, pois melhorou a fertilidade dos solos e pode vir a reduzir custos com manejo do solo e adubação das culturas.
\end{abstract}

Termos para indexação: Resíduo de saneamento; calagem; recuperação de fósforo; fonte de nutrientes; matéria orgânica.

\section{INTRODUCTION}

The application of sewage sludge to agricultural soils is one strategy used to recycle this type of waste. One of the main reasons for the agricultural use of sewage sludge is that, because of the addition of significant amounts of organic matter and some elements essential to plants, sludge can improve the chemical, physical, and biological attributes of soil (Maio et al., 2011; Mondal et al., 2015).
The greater accessibility of urban households to the sewage collection and treatment network (Venson; Rodrigues; Camara, 2015) has resulted in the generation of residues with different characteristics because of different eating habits in each region, the amount of sludge generated, and the operating conditions of sewage treatment plants (Healy et al., 2016). Furthermore, sludge transportation cost is burdensome and hinders distribution over long distances (Quintana; Bueno; Melo, 2012). Therefore, the 
recommendation is for disposal to agricultural areas nearby sewage treatment plants, which justifies the specific studies considering characteristics of local soils and sludge.

Regardless of the final destination, the sludge goes through processes or treatments to ensure that this residue is not a source of pathogens. One of these treatments is prolonged alkaline stabilization (PAS), the principle of which is the elimination of pathogens by increasing the $\mathrm{pH}$ of the sludge to levels equal to or greater than 12 , which is accomplished by the addition of $\mathrm{CaO}$ or $\mathrm{CaO}+\mathrm{MgO}$ (Bittencourt et al., 2014). In countries such as Brazil, the United States, Canada, Turkey, Ireland, and South Africa, prolonged alkalization is one of the methods used to sanitize sewage sludge (LeBlanc; Matthews; Richard, 2008; Healy et al., 2016).

When applied to acid soils, alkalinized sewage sludge causes soil $\mathrm{pH}$ and the exchangeable content of $\mathrm{Ca}^{2+}$ and $\mathrm{Mg}^{2+}$ to rise, and the exchangeable acidity $\left(\mathrm{Al}^{3+}\right)$ and potential acidity $\left(\mathrm{H}+\mathrm{Al}^{3+}\right)$ to decrease, similar to the results of dolomitic limestone application (Corrêa et al., 2007; Serrat et al., 2011). Conversely, unlike limestone, alkalinized sewage sludge adds considerable amounts of organic compounds, $\mathrm{P}$, and $\mathrm{K}$ to the soil (Bittencourt et al., 2014). However, there is limited knowledge regarding the effects of alkalinized sewage sludge on $P$ and $K$ availability and organic C content in soil, parallel with the evaluation of other soil fertility indicators, such as $\mathrm{Al}^{3+}$ content, cation exchange capacity, and base saturation. Thus, the goal of the study was to evaluate how the application of alkalinized sewage sludge affects the fertility of acid soil.

\section{MATERIAL AND METHODS}

A sewage treatment plant from the sector municipal headquarters was selected from 20 Sanitation Company of Paraná (SANEPAR; Paraná State, Brazil) sectors. Samples of fresh sludge (generated by anaerobic treatment) were collected between March 2009 and August 2010. The sludge was sanitized by curing with lime $(\mathrm{CaO}$ and $\mathrm{MgO}$, relative total neutralization power [RTNP] 105.1\%) at 50\% total solids for 30 days. The main type of agricultural soil in the region was selected for each sector from which sewage sludge was collected (Figure 1). Soil samples were taken from the $0-20 \mathrm{~cm}$ layer in areas that had not been treated with limestone for the last five years. Soil samples were air dried, sieved through a mesh $(2 \mathrm{~mm})$ and, granulometric and chemical attributes were determined. The results of the granulometric and chemical analyses, and soil classes are presented in Table 1 (Poggere et al., 2012).

In the laboratory, the alkalinized sewage sludge was incubated with the soil from its respective region. An official methodology was used, described in BRASIL (2006). Each soil was incubated with sewage sludge $(0,10,20,40$, or

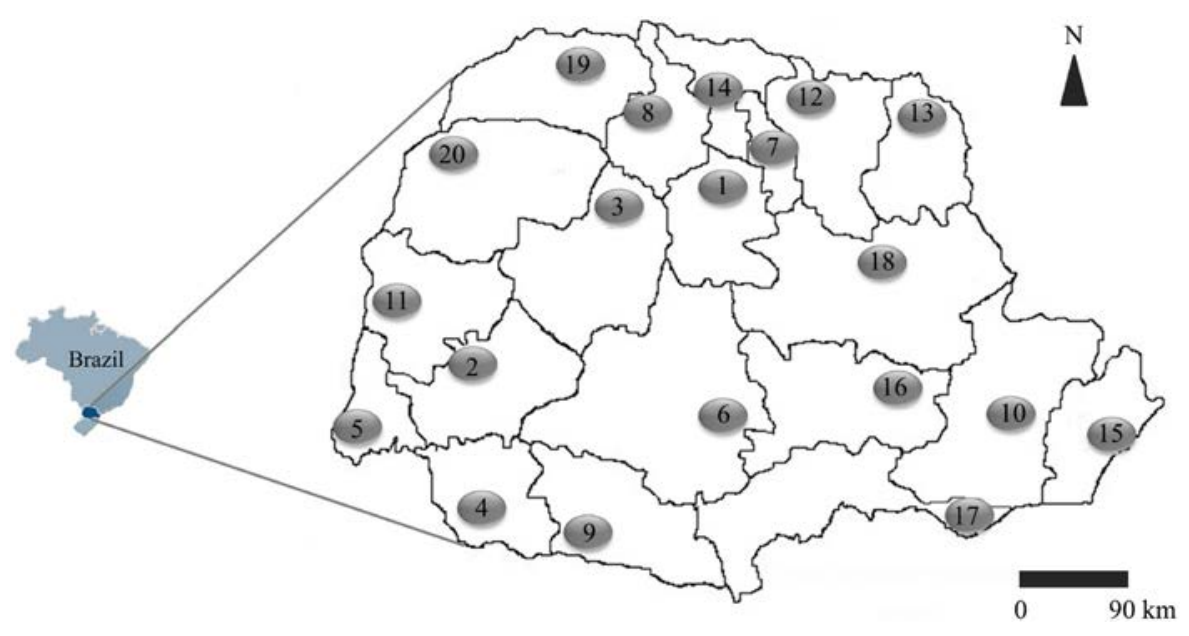

Figure 1: Map of Paraná State (Brazil) with divisions for the 20 Sanitation Company of Paraná sectors from which sewage sludge and the primary agricultural soil were collected. Sectors: 1 - Apucarana; 2 - Cascavel; 3 Campo Mourão; 4 - Francisco Beltrão; 5 - Foz do Iguaçu; 6 - Guarapuava; 7 - Londrina; 8 - Maringá; 9 - Pato Branco; 10 - Curitiba metropolitan region (CMR); 11 - Toledo; 12 - Cornélio Procópio; 13 - Santo Antônio da Platina; 14 Arapongas; 15 - Litoral; 16 - Ponta Grossa; 17 - União da Vitória; 18 - Telêmaco Borba; 19 - Paranavaí; 20 - Umuarama. The soil sampling was conducted in the same municipality for which the sector was named, except for Curitiba metropolitan region (CMR), Arapongas, Litoral, and União da Vitória, where the soil was collected in the municipality of Pinhais, Maringá, Matinhos, and Rio Negro, respectively. 
$80 \mathrm{Mg} \mathrm{ha}^{-1}$ total solids) for 60 days. The sewage sludge composition after sanitization is presented in Table 2. In addition, the soils were incubated with doses of dolomitic limestone (RTNP 101.3\%) in attempt to reach soil base saturation similar to that of the alkalinized sewage sludge treated soils. After the incubation period, soil samples were air dried and sieved through a mesh (2 mm).

For soil samples, the following attributes were determined: $\mathrm{pH}$ (in $0.01 \mathrm{~mol} \mathrm{~L}^{-1} \mathrm{CaCl}_{2}$; soil ratio: 1:2.5 solution); $\mathrm{Ca}^{2+}$ and $\mathrm{Mg}^{2+}\left(1 \mathrm{~mol} \mathrm{~L}{ }^{-1} \mathrm{KCl}\right.$ extractor; determination with Varian AA240FS atomic absorption spectrophotometer); $\mathrm{Al}^{3+}$ (extractor $1 \mathrm{~mol} \mathrm{~L}^{-1} \mathrm{KCl}$; titration with $\mathrm{NaOH}$ ); organic carbon (OC) (volumetric method by potassium dichromate); $\mathrm{K}^{+}$(Mehlich-1 extractor; determination with a Digimed MD-62 flame spectrophotometer); P (Mehlich-1 extractor; determination with UV/Vis Bel Photonics SP2000 spectrophotometer, via the molybdenum blue method); the cation exchange capacity effective (CECe) was obtained by summing the total amount of bases $\left(\mathrm{Ca}^{2+}, \mathrm{Mg}^{2+}, \mathrm{K}^{+}\right)$and $\mathrm{Al}^{3+}$; the cation exchange capacity potential (CECp) was obtained by summing the bases $\left(\mathrm{Ca}^{2+}, \mathrm{Mg}^{2+}, \mathrm{K}^{+}\right)$and $\mathrm{H}+\mathrm{Al}^{3+}$; the base saturation was established by the percentage of CEC load occupied by the exchangeable bases $\left(\mathrm{Ca}^{2+}, \mathrm{Mg}^{2+}\right.$ and $\mathrm{K}^{+}$), as described in Embrapa (2011); $\mathrm{H}+\mathrm{Al}^{3+}$ estimated by pH-SMP as described in Pavan et al. (1991).

Table 1: Classification and properties of the soil used in the incubation process with alkalized sewage sludge from Paraná State, Brazil.

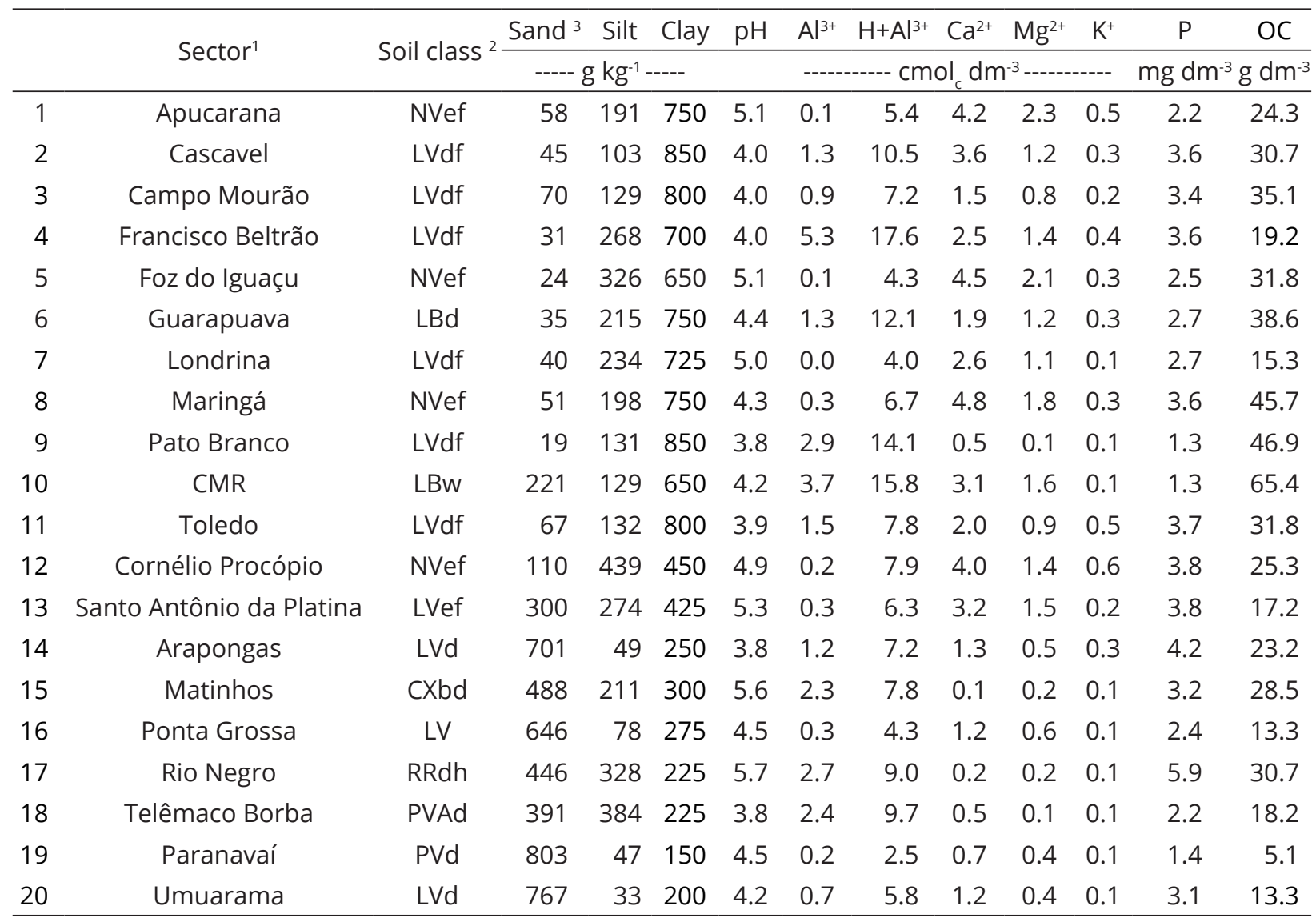

${ }^{1}$ Soil sampling was conducted in the same municipality for which the sector was named, except for CMR, Arapongas, Litoral, and União da Vitória, where the soil was collected in the municipality of Pinhais, Maringá, Matinhos, and Rio Negro, respectively. ${ }^{2}$ Soil classification in the sector containing the soil sample collection site, according to Bhering and Santos (2008); LVdf: Latossolo Vermelho Distroférrico; Lbw: Latossolo Bruno Ácrico; Lbd: Latossolo Bruno Distrófico; Nvef: Nitossolo Vermelho Eutroférrico; Rrdh: Neossolo Regolítico DistroHúmbrico; Cxbd = Cambissolo Háplico Tb Distrófico; Pvad: Argissolo Vermelho-Amarelo Distrófico; Lvd: Latossolo Vermelho Distrófico; LV: Latossolo Vermelho; ${ }^{3}$ Soil analysis: granulometry by the densimeter method; $\mathrm{pH}-\mathrm{CaCl}_{2} ; \mathrm{Ca}^{2+}, \mathrm{Mg}^{2+}, \mathrm{Al}^{3+}\left(\mathrm{extracted} \mathrm{with} \mathrm{KCl} 1 \mathrm{~mol} \mathrm{~L}{ }^{-1}\right.$ ); $\mathrm{H}+\mathrm{Al}^{3+}$ (estimated by $\mathrm{pH}-\mathrm{SMP}$ ); organic carbon (OC) (volumetric method by potassium dichromate); $\mathrm{K}^{+}$and $\mathrm{P}$ (Mehlich-1 extraction). 
Table 2: $\mathrm{C} / \mathrm{N}$ ratio and total $\mathrm{C}, \mathrm{N}, \mathrm{Ca}, \mathrm{Mg}, \mathrm{K}$, and $\mathrm{P}$ content $\left(\mathrm{l} ; \mathrm{g} \mathrm{kg}^{-1}\right)$ or with $10 \mathrm{Mg} \mathrm{ha}^{-1}\left(\mathrm{Il} ; \mathrm{kg} \mathrm{ha}^{-1}\right)$ for 20 alkalinized sewage sludges from Paraná State (Brazil).

\begin{tabular}{|c|c|c|c|c|c|c|c|c|c|c|c|c|c|}
\hline \multirow{2}{*}{ Sector } & \multirow[t]{2}{*}{$\mathrm{C} / \mathrm{N}$} & \multicolumn{2}{|c|}{ C } & \multicolumn{2}{|c|}{ N } & \multicolumn{2}{|c|}{$\mathrm{Ca}$} & \multicolumn{2}{|r|}{$\mathrm{Mg}$} & \multicolumn{2}{|c|}{ K } & \multicolumn{2}{|c|}{$P$} \\
\hline & & 1 & II & 1 & II & 1 & II & 1 & II & 1 & II & 1 & II \\
\hline Apucarana & 12 & 100 & 1000 & 8.0 & 80 & 133 & 1338 & 17 & 170 & 0.5 & 5.0 & 5.8 & 58 \\
\hline Cascavel & 12 & 189 & 1894 & 16.0 & 160 & 143 & 1439 & 17 & 170 & 0.7 & 7.0 & 7.5 & 75 \\
\hline Campo Mourão & 10 & 127 & 1273 & 13.1 & 131 & 139 & 1391 & 17 & 173 & 0.7 & 7.0 & 5.9 & 59 \\
\hline Francisco Beltrão & 10 & 147 & 1473 & 14.3 & 143 & 144 & 1440 & 17 & 176 & 0.4 & 4.0 & 6.3 & 63 \\
\hline Foz do Iguaçu & 11 & 112 & 1121 & 10.0 & 100 & 146 & 1467 & 17 & 177 & 0.4 & 4.0 & 6.3 & 63 \\
\hline Guarapuava & 11 & 146 & 1462 & 13.0 & 130 & 131 & 1318 & 17 & 170 & 0.5 & 5.0 & 7.1 & 71 \\
\hline Londrina & 10 & 187 & 1878 & 18.0 & 180 & 145 & 1456 & 17 & 175 & 0.5 & 5.0 & 7.7 & 77 \\
\hline Maringá & 10 & 175 & 1756 & 17.0 & 170 & 138 & 1380 & 17 & 172 & 0.4 & 4.0 & 9.5 & 95 \\
\hline Pato Branc & 10 & 145 & 1450 & 14.0 & 140 & 127 & 1274 & 16 & 169 & 0.4 & 4.0 & 7.7 & 77 \\
\hline $\mathrm{CMR}^{1}$ & 13 & 113 & 1130 & 8.8 & 88 & 122 & 1225 & 17 & 170 & 0.7 & 7.0 & 6.7 & 67 \\
\hline Toledo & 11 & 165 & 1656 & 15.0 & 150 & 140 & 1405 & 17 & 173 & 0.9 & 9.0 & 6.0 & 60 \\
\hline Cornélio Procópio & 13 & 101 & 1013 & 8.0 & 80 & 150 & 1507 & 17 & 177 & 0.4 & 4.0 & 6.5 & 65 \\
\hline Santo Antonio da Platina & 11 & 145 & 1453 & 13.2 & 132 & 142 & 1423 & 17 & 173 & 0.5 & 5.0 & 6.7 & 67 \\
\hline Arapongas & 10 & 219 & 2197 & 22.0 & 220 & 145 & 1450 & 17 & 174 & 0.7 & 7.0 & 7.7 & 77 \\
\hline Litoral & 11 & 145 & 1450 & 12.8 & 128 & 163 & 1630 & 18 & 186 & 0.5 & 5.0 & 6.7 & 67 \\
\hline Ponta Grossa & 9 & 139 & 1392 & 15.0 & 150 & 157 & 1573 & 18 & 181 & 0.6 & 6.0 & 6.9 & 69 \\
\hline União da Vitória & 11 & 110 & 1103 & 10.0 & 100 & 140 & 1405 & 17 & 175 & 0.8 & 8.0 & 7.3 & 73 \\
\hline Telêmaco Borba & 9 & 159 & 1596 & 17.0 & 170 & 140 & 1400 & 17 & 172 & 0.8 & 8.0 & 8.0 & 80 \\
\hline Paranavaí & 10 & 199 & 1992 & 18.2 & 182 & 142 & 1420 & 17 & 173 & 0.7 & 7.0 & 7.0 & 70 \\
\hline Umuarama & 12 & 152 & 1520 & 12.4 & 124 & 142 & 1423 & 17 & 175 & 0.5 & 5.0 & 6.4 & 64 \\
\hline Mean & 11 & 149 & 1490 & 14 & 138 & 142 & 1418 & 17 & 174 & 0.6 & 6.0 & 7.0 & 70 \\
\hline Standard deviation & 1.0 & 33 & 334 & 3.7 & 37 & 9.2 & 91 & 0.4 & 4.1 & 0.2 & 1.6 & 0.9 & 8.8 \\
\hline
\end{tabular}

${ }^{1}$ CMR: Curitiba metropolitan region.

The P recovery efficiency (by Mehlich-1 extraction) was determined using the following Equation 1:

$\mathrm{ER}=\frac{((\text { Czero }- \text { Css }) * 2)}{\text { EASS }} * 100$

where: ER, element recovery (\%); Czero, element content in soil without alkalinized sewage sludge application (mg $\mathrm{kg}^{-1}$ ); Css, element content in soil with alkalinized sewage sludge application ( $\left.\mathrm{mg} \mathrm{kg}^{-1}\right)$; EASS, element addition with alkalinized sewage sludge $\left(\mathrm{kg} \mathrm{ha}^{-1}\right)$ (Dalpisol et al., 2017).

The data were submitted to an analysis of variance (ANOVA) using a completely randomized design, with five alkalinized sewage sludge doses $(0,10,20,40$, and
$80 \mathrm{Mg} \mathrm{ha}^{-1}$ ) in triplicate, for each of the 20 soils evaluated. If the ANOVA was significant ( $p<0.05$ ), the data were submitted to regression analysis and the model with the highest determination coefficient $\left(\mathrm{R}^{2}\right)$ and significance $(p<0.05$ or $p<0.01)$ was chosen. In addition, Pearson correlation coefficients were obtained for each attribute analyzed in soils incubated with alkalinized sewage sludge and in soils incubated with limestone.

\section{RESULTS AND DISCUSSION}

The increase in the $\mathrm{pH}-\mathrm{CaCl}_{2}$ of the soils treated with alkalinized sewage sludge (Figure 2A) was consistent with previous studies using this type of sludge (Corrêa et al., 2007; Tamanini et al., 2008; Serrat et al., 2011) or other 
alkaline organic residues (Pértile et al., 2012; Neto et al., 2016). However, the highest $\mathrm{pH}-\mathrm{CaCl}_{2}$ values were reached in the soils of medium texture, and this was like caused by the lower buffering power of these soils, as is evidenced by their lower $\mathrm{H}+\mathrm{Al}^{3+}$ values (Figure 2C). This occurs because low-clay mineral soils (usually associated with lower organic $\mathrm{C}$ content) have lower $\mathrm{H}^{+}$buffering capacity in solution (Resburg; Claassens; Beukes, 2009) and as a result, they have a lower capacity to withstand the $\mathrm{pH}$ increase caused by the addition of alkaline material. In practical terms, the agricultural use of alkaline sewage sludge will be limited by its ability to raise the $\mathrm{pH}$ to values above those considered adequate. For soils of medium and clayey texture, the dose of sludge required to raise the $\mathrm{pH}-\mathrm{CaCl}_{2}$ to 6 varies between 10 and $20 \mathrm{Mg} \mathrm{ha}^{-1}$, whereas for very clayey soils it is between 10 and $60 \mathrm{Mg} \mathrm{ha}^{-1}$. This variation is highlighted in a specific study on the recommendation for liming requirements (Poggere et al., 2012).

The decrease of $\mathrm{Al}^{3+}$ content in soils after application of alkalinized sewage sludge (Figure 2B) is related to the decline in soil acidity (Figure 2A). Furthermore, the influence of $\mathrm{pH}$ is so great that, in acid soils with $\mathrm{pH}$ $\mathrm{CaCl}_{2}$ above $5, \mathrm{Al}^{3+}$ tends to completely precipitate into insoluble forms [such as $\mathrm{Al}\left(\mathrm{OH}_{3}\right)$ ] and stable complexes
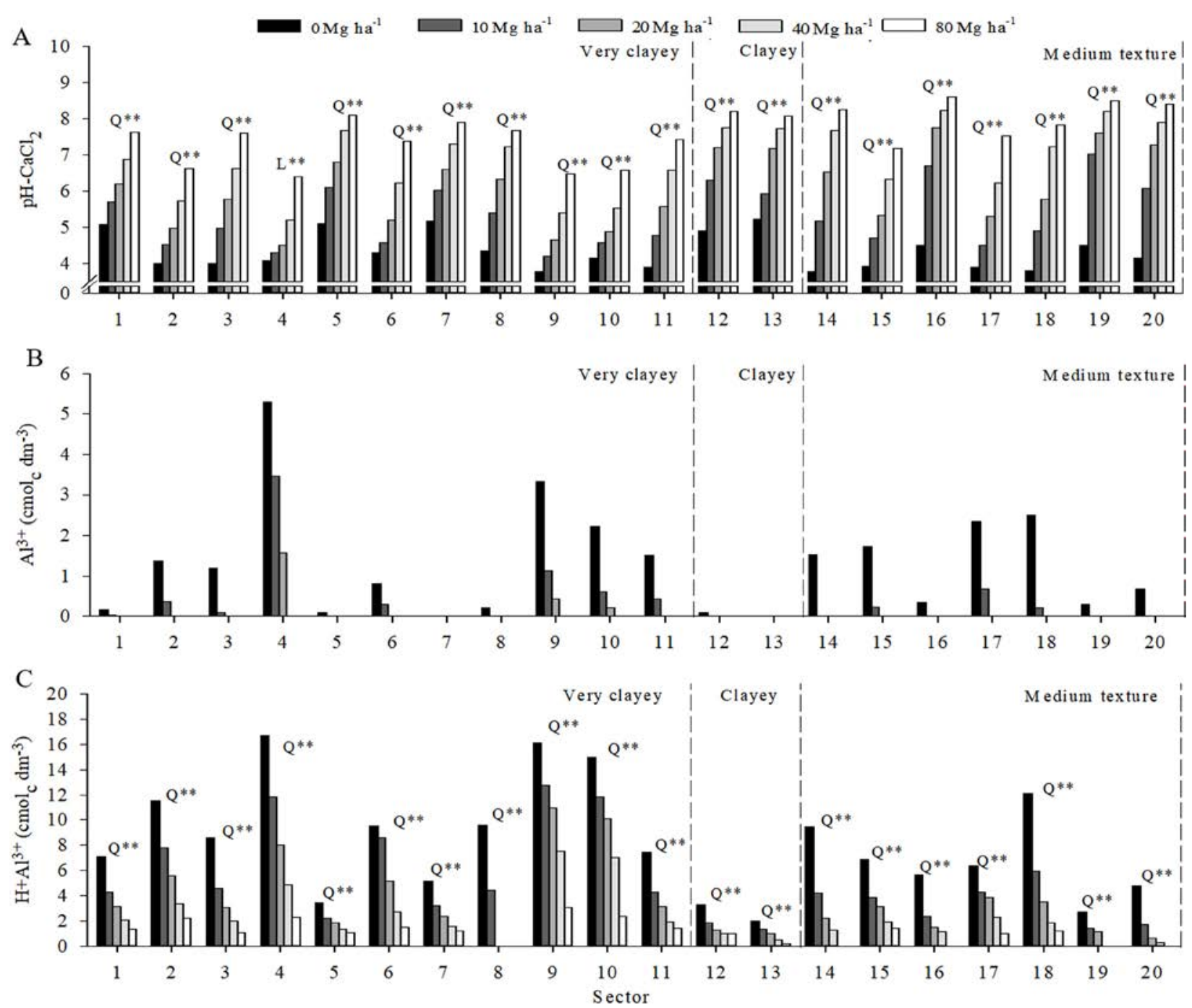

Figure 2: $\mathrm{pH}_{-}-\mathrm{CaCl}_{2}(\mathrm{~A}), \mathrm{Al}^{3+}(\mathrm{B})$, and $\mathrm{H}+\mathrm{Al}^{3+}(\mathrm{C})$ for soils of Paraná State (Brazil) as a function of increasing application rates of sludge from their respective sector. $L$ and $Q$ correspond to linear or quadratic regression adjustments, respectively. ${ }^{* *}$, significant regression at $p<0.01$. 
with humic substances (Nogueirol; Monteiro; Azevedo, 2015). This explains the lack of detection of $\mathrm{Al}^{3+}$ (extracted with $1 \mathrm{~mol} \mathrm{~L}^{-1} \mathrm{KCl}$ ) for the majority of soils with the first (10 $\left.\mathrm{Mg} \mathrm{ha}^{-1}\right)$ or second (20 $\left.\mathrm{Mg} \mathrm{ha}^{-1}\right)$ alkalinized sewage sludge dose (Figure 2B).

For all 20 studied soils, $\mathrm{Ca}^{2+}$ (Figure $3 \mathrm{~A}$ ) and $\mathrm{Mg}^{2+}$ (Figure 3B) increased with the application of alkalinized sewage sludge doses because of the high levels of these two nutrients in all the sludge studied (Table 2). Our results were similar to those of Marin et al. (2010) using alkalinized sewage sludge and by Pértile et al. (2012) using alkaline waste from the pulp industry. Thus, alkalinized sewage sludge is an interesting alternative source of $\mathrm{Ca}$ and $\mathrm{Mg}$, although complementary evaluations using cultivated plants should be explored in further studies.

The $\mathrm{K}^{+}$levels (Figure 3C) increased in seven soils, whereas the reverse occurred in six; however, the variation did not imply that the soil $\mathrm{K}^{+}$interpretation class was altered (Raij et al., 1997). According to Bittencourt et al. (2014), the main reason for the reduced efficiency of alkalinized sewage sludge as a K source is its low content in the sludge (the lowest of the macronutrients), which occurs because of the loss of this nutrient via effluents during the treatment process. Other studies likewise reported little influence on the soil $\mathrm{K}^{+}$interpretation class for non-alkalinized sewage sludge (Bettiol; Ghini, 2011; Carmo; Lima; Silva, 2016). For practical application, however, the K supply available to cultivated plants, from other sources of this nutrient, must be determined.

With the addition of sludge, the effective cation exchange capacity (CECe) (Figure 3D) increased similar to that of $\mathrm{Ca}^{2+}$ and $\mathrm{Mg}^{2+}$, and the decrease in $\mathrm{Al}^{3+}$ content did not affect the results. Conversely, of the 20 evaluated soils, the application of alkalinized sewage sludge increased the potential CEC in 11 soils, decreased it in five soils, and in the other soils the levels were variable, increasing or decreasing depending on the sludge dose (Figure 3E). The increase of soil CEC was the predominant effect caused by the increase in soil $\mathrm{Ca}^{2+}, \mathrm{Mg}^{2+}$, and $\mathrm{pH}-\mathrm{CaCl}_{2}$ following the application of alkalinized sewage sludge. The increase in $\mathrm{pH}-\mathrm{CaCl}_{2}$ generally favors the formation of negative charges on the surface of clay minerals and humic substances (mainly carboxylic groups and phenolics) in soils of variable charges (Sposito, 2008). However, the decrease in the potential CEC of five soils was related to the significant decrease in the potential acidity $\left(\mathrm{H}+\mathrm{Al}^{3+}\right)$ values with the application of sludge, especially the levels of $\mathrm{H}$. Thus, the decrease in $\mathrm{H}$ values was of similar importance as the increase in $\mathrm{Ca}^{2+}$ and $\mathrm{Mg}^{2+}$ values in the decrease of potential CEC.
Initial base saturation values ranged from 4.8 to $73 \%$, and alkalinized sewage sludge increased base saturation in the 20 evaluated soils, ranging from 79 to $100 \%$ (Figure 4A). This significant increase occurred primarily because of the addition of $\mathrm{Ca}$ and $\mathrm{Mg}$ to the soil, because $\mathrm{K}$ did not increase in most soils in response to sludge application (Figure 3).

Alkalinized sewage sludge increased the organic $\mathrm{C}$ levels in three soils (all NVef), but did not affect the other 17 evaluated soils (Figure 4B). Thus, sludge application can be considered beneficial because $\mathrm{C}$ is a key factor in soil quality (Lal, 2015). Tamanini et al. (2008) similarly reported a linear increase of organic $\mathrm{C}$ in degraded soil after the application of alkaline sewage sludge. Marin et al. (2010) using alkaline sewage sludge, and Neto et al. (2016) using alkaline residues from the pharmaceutical industry did not detect an effect on soil organic C. However, the increase in organic $\mathrm{C}$ content (Figure 4B) was not related to the amount of $\mathrm{C}$ added via the sludge (Table 2). Thus, the variation was probably related to specific interactions between the alkalinized sewage sludge and soil composition factors that affect organic waste decomposition. Therefore, long-term studies to verify the effects of alkalinized sewage sludge on soil organic matter are necessary.

The significant increase in available $\mathrm{P}$ in soils treated with alkalinized sewage sludge (Figure 4C) was caused by the high levels of this nutrient in the sludge (Table 2). Other studies found similar results with the application of sewage sludge and animal waste (Barcellos et al., 2015, Carmo; Lima; Silva, 2016). The use of 20 soils and sludges in the present study allowed us to verify interesting variations regarding P availability and P recovery (Figure 4D).

In general, in many clayey soils, the availability and recovery of $\mathrm{P}$ were lower in comparison to that of medium-texture soils because the specific adsorption capacity of $\mathrm{P}$ is positively related to clay content (Gérard, 2016). However, two soils were clearly exceptions, and did not follow this relationship for $\mathrm{P}$ availability in terms of clay content. First, the soil of the Maringá sector (Sector 8; Figure 4C), although very clayey, exhibited a very high increase in P availability. Second, the Ponta Grossa sector (Sector 16; Figure 4C) soil had a medium texture, but a P availability similar to that found in most clayey soils. In the first exception, the fact that Maringá sludge contained the highest amount of P $\left(9.5 \mathrm{~g} \mathrm{~kg}^{-1}\right)$ (Table 2) may have contributed to the results. Furthermore, the adsorption capacity decreases as P application increases, and consequently it is likely that this soil had high $\mathrm{P}$ concentrations in the past. In the second exception, it is possible that the soil of Ponta Grossa has solid phase components with higher sorption capacity for P. 


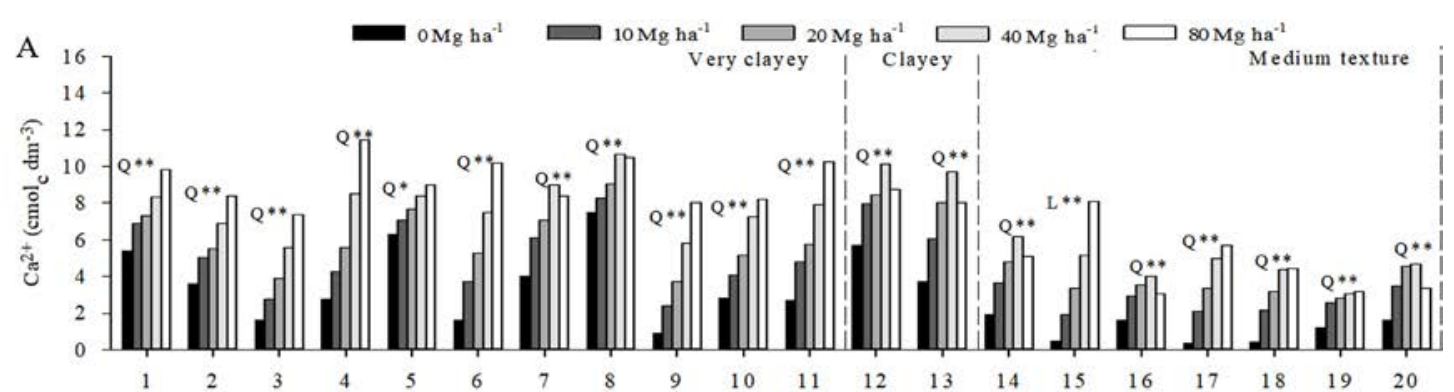

B
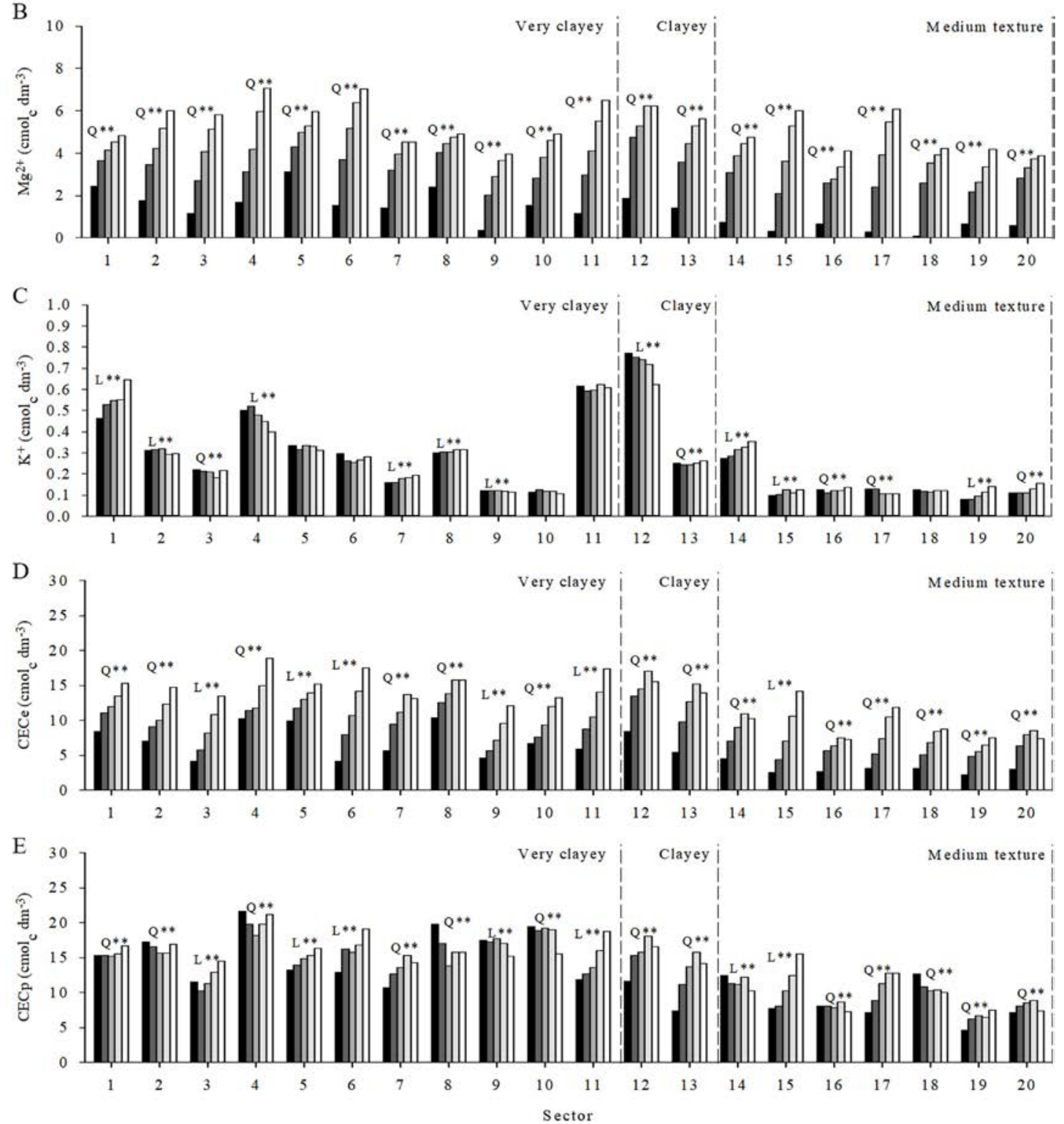

Figure 3: Available levels of $\mathrm{Ca}^{2+}(\mathrm{A}), \mathrm{Mg}^{2+}(\mathrm{B}), \mathrm{K}^{+}(\mathrm{C})$, effective cation exchange capacity (CECe) (D), and potential cation exchange capacity (CECP) (E) in soils of Paraná State (Brazil) as a function of increasing application rates of sludge from their respective sector. $L$ and $Q$ correspond to linear or quadratic regression adjustments, respectively. ${ }^{* *}$, significant regression at $p<0.01$. 


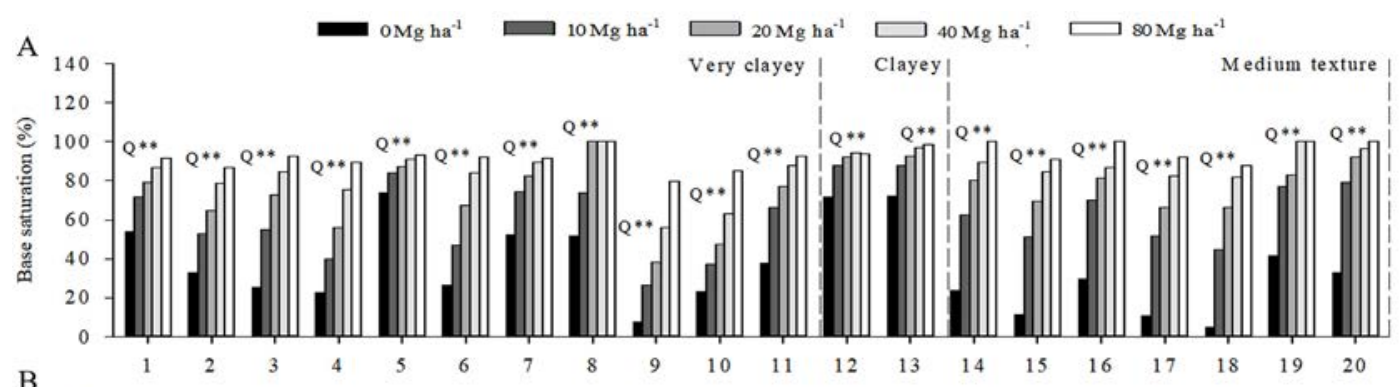

$\mathrm{B}$
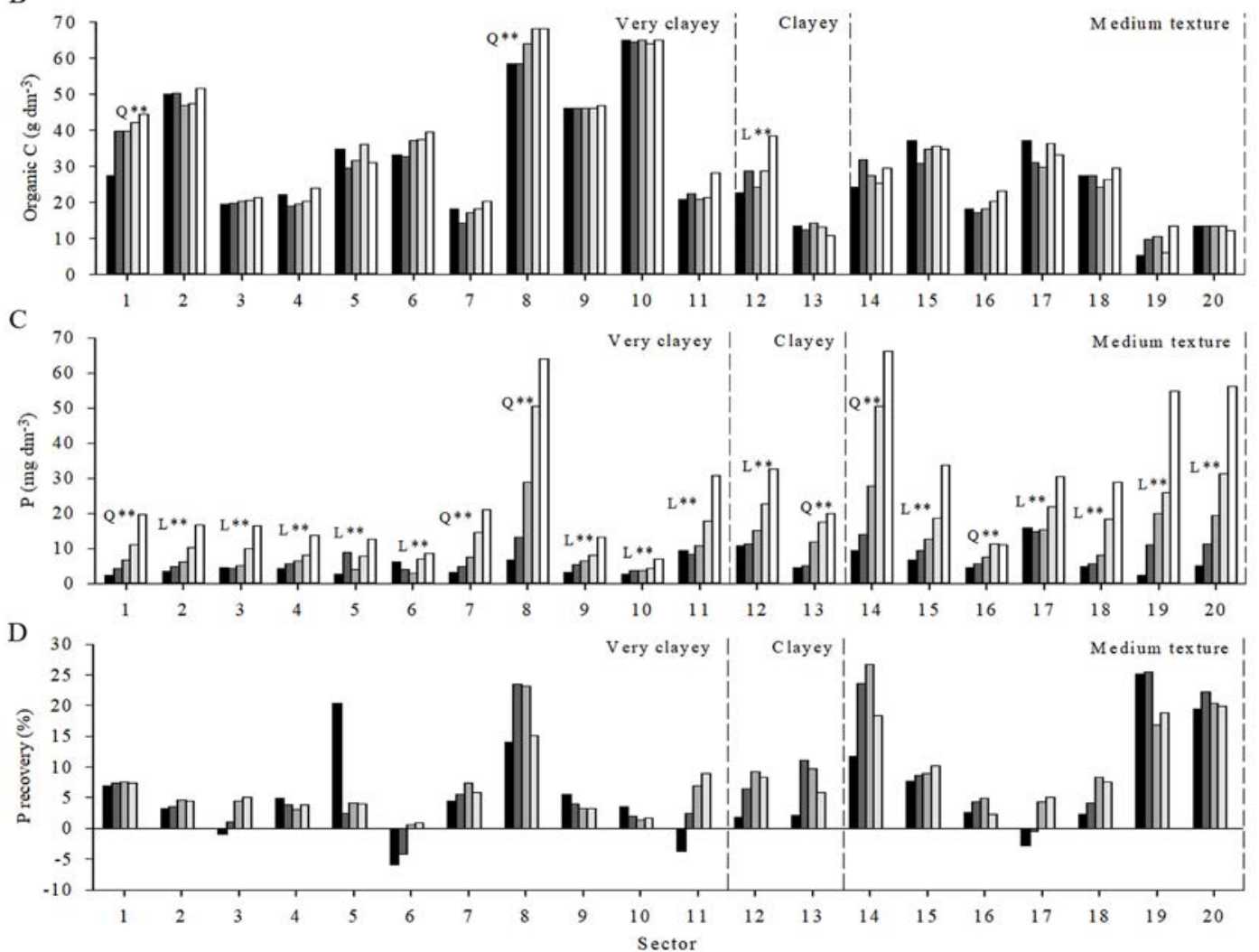

Figure 4: Base saturation (A), organic carbon (B), available $P(C)$, and recovery of $P(D)$ in soils of Paraná State (Brazil) as a function of increasing application rates of sludge from their respective sector. $L$ and $Q$ correspond to linear or quadratic regression adjustments, respectively. ${ }^{* *}$, significant regression at $p<0.01$.

The soil of Guarapuava (Sector 6, Figure 4C), which exhibited the lowest $\mathrm{P}$ recovery rate among the 20 studied soils, had a high P buffering capability. The high degree of weathering and abundance of goethite and gibbsite (oxides with high $\mathrm{P}$ adsorption capacity) found in Guarapuava soils, higher than those commonly found in other types of soils formed from basalt, (Bayer; Bissani; Zanatta, 2006), may explain the lower increases in available $\mathrm{P}$ in the soil and the low recovery by the Mehlich-1 extractor. The results were probably dependent on organo-mineralogical and mineralogical interactions of the clay fraction with higher or lower P adsorption capacity (Fink et al., 2016; Gérard, 2016).

The correlations between chemical attributes of the soils incubated with alkalinized sewage sludge versus the soils incubated with limestone are presented in Figure 5. The higher $\mathrm{pH}-\mathrm{CaCl}_{2}$ and $\mathrm{Ca}^{2+}$ values in soils incubated with alkalinized sewage sludge compared to those of soils treated with the use of limestone were associated with the difference in the alkalinizing components of each material. The treatment of sludge by the PAS process occurred through the addition of lime $(\mathrm{CaO})$, which has greater 
solubility and acidity correction capacity than Ca carbonate $\left(\mathrm{CaCO}_{3}\right)$, which is the main component of limestone. Additionally, the $\mathrm{CaCO}_{3}$ reaction slows substantially when $\mathrm{pH}-\mathrm{CaCl}_{2}$ exceeds 6.5, unlike that of $\mathrm{CaO}$ (Allen; Hossner, 1991; Alcarde; Rodella, 2003). Corrêa et al. (2007) and Serrat et al. (2011) reported similar results regarding the use of alkalinized sewage sludge compared to limestone. Conversely, soil organic carbon following the application of alkaline sewage sludge and limestone was correlated, although limestone did not add this mineral. Although alkaline sewage sludge added carbon, it had a positive effect on only three soils (Figure 4B). Therefore, both sludge and limestone had little effect on organic carbon.

We observed a correlation for $\mathrm{P}$ availability (Figure 5K) following the application of sludge and limestone, except for $\mathrm{P}$ in medium-texture soil. This was
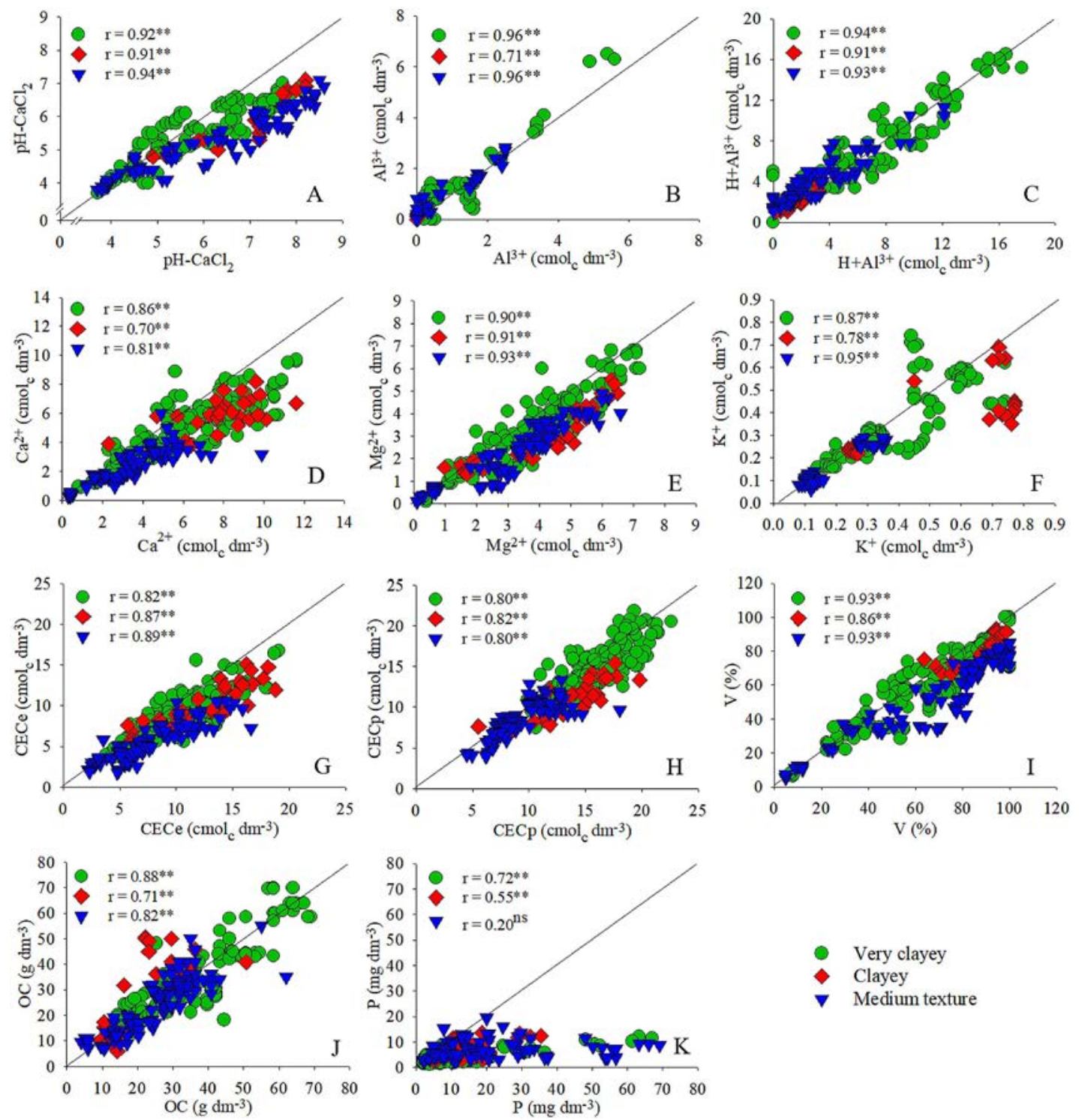

Figure 5: Pearson correlation coefficients between soil fertility attributes after 60 days of incubation with alkalinized sewage sludge (X axis) and limestone (Y axis). $\mathrm{pH}-\mathrm{CaCl}_{2}(\mathrm{~A}), \mathrm{Al}^{3+}(\mathrm{B}), \mathrm{H}+\mathrm{Al}{ }^{3+}(\mathrm{C}), \mathrm{Ca}^{2+}(\mathrm{D}), \mathrm{Mg}^{2+}(\mathrm{E}), \mathrm{K}^{+}(\mathrm{F})$, effective cation exchange capacity - CECe (G), potential cation exchange capacity (CECP) (H), base saturation - V (I), organic carbon $(\mathrm{J})$, and $\mathrm{P}(\mathrm{K})$. **, correlation significant $p<0.01$. Ns, not significant. Very clayey $(\mathrm{n}=165)$, clayey $(\mathrm{n}$ $=30)$, and medium texture $(n=105)$. 
expected because of the high $\mathrm{P}$ addition via sludge. The indirect effect caused by the increase in soil $\mathrm{pH}$ was not very effective following the limestone application. Considering the concerns regarding fertilizer use, $\mathrm{P}$ recovery, and cost of phosphate fertilization in agricultural soils (Roy et al., 2016), alkalinized sewage sludge can be considered an alternative source of P. In addition, according Bittencourt et al. (2014), 88,166 Mg of alkalinized sewage sludge destined for 2,288 ha of agricultural areas (corn, soybean, bean, oat, wheat, green manure, and stone fruit trees), provided $88 \%$ lime, $74 \% \mathrm{~N}, 73 \% \mathrm{P}_{2} \mathrm{O}_{5}$, and $35 \% \mathrm{~K}_{2} \mathrm{O}$ for crop fertilization. In the same study, 80 farmers benefited from a reduced expense for fertilizers and limestone, saving an average of US $\$ 813.45$ per ha. Thus, the use of alkaline sewage sludge in acid soils should be encouraged in agricultural areas near sewage treatment plants.

\section{CONCLUSIONS}

Alkalinized sewage sludge application to soil resulted in the decrease of exchangeable acidity $\left(\mathrm{Al}^{3+}\right)$ and potential acidity $\left(\mathrm{H}+\mathrm{Al}^{3+}\right)$, and the increase of $\mathrm{pH}-\mathrm{CaCl}_{2}$, available $\mathrm{P}$, $\mathrm{Ca}^{2+}, \mathrm{Mg}^{2+}$, base saturation, and effective cation exchange capacity. Diverse effect on available $\mathrm{K}^{+}$and potential cation exchange capacity was observed. However, organic $\mathrm{C}$ was least influenced by the sludge, with an increase observed only in three soils. Additionally, the corrective action of the alkalinized sewage sludge was superior to that of limestone, with a greater $\mathrm{Ca}^{2+}$ and $\mathrm{pH}-\mathrm{CaCl}_{2}$ increase. Similar to limestone, alkalinized sewage sludge caused a decrease in $\mathrm{Al}^{3+}$ and $\mathrm{H}^{+} \mathrm{Al}^{3+}$, and an increase in $\mathrm{Mg}^{2+}$. Consequently, our results indicated that the alkalinized sewage sludge is an interesting alternative with which to improve the fertility of acid soils, considering that very clayey soils (higher buffering capacity) should receive a higher sludge dose in comparison with clayey and medium-texture soils.

\section{ACKNOWLEDGEMENTS}

To CAPES, CNPq, Fundação Araucária and SANEPAR.

\section{REFERENCES}

ALCARDE, J. A.; RODELLA, A. A. Qualidade e legislação de fertilizantes e corretivos. In: CURI, N. et al. Tópicos em Ciência do Solo. Viçosa, Sociedade brasileira de Ciência do Solo, 2003. p.291-334.
ALLEN, E. R.; HOSSNER, L. R. Factors affecting the accumulation of surface applied agricultural limestone in permanent pastures. Soil Science, 151(3):240-248, 1991.

BARCELLOS, M. et al. Atributos químicos de Latossolo sob plantio direto adubado com esterco de bovinos e fertilizantes minerais. Comunicata Scientiae, 6(3):263-273, 2015.

BAYER, C.; BISSANI, C. A.; ZANATTA, J. A. Química de solos em plantio direto. In: FONTOURA, S. M. V.; BAYER, C. (eds). Manejo da fertilidade de solos em plantio direto. Guarapuava: Fapa, 2006. p.7-26.

BHERING, S. B.; SANTOS, H. G. Mapa de solos do Estado do Paraná: Legenda atualizada. Rio de Janeiro, EMBRAPAIAPAR, 2008. 74p.

BETTIOL, W.; GHINI, R. Impacts of sewage sludge in tropical soil: A case study in Brazil. Applied and Environmental Soil Science, 2011. Available in: <https://www.hindawi.com/ journals/aess/2011/212807/>. Access in: February 28, 2017.

BITTENCOURT, S. et al. Sewage sludge usage in agriculture: A case study of its destination in the Curitiba Metropolitan Region, Paraná, Brazil. Water, Air and Soil Pollution, 225:2074, 2014

BRASIL. Ministério do Meio Ambiente. Conselho Nacional do Meio Ambiente. (2006). Resolução CONAMA n³75, de 29 de agosto de 2006. Define critérios e procedimentos, para o uso agrícola de lodos de esgoto gerados em estações de tratamento de esgoto sanitário. Available in: <www.mma. gov.br/port/conama/res/res06/res37506.pdf>. Access in Jun 9, 2016.

CARMO, D. L. D.; LIMA, L. B.; SILVA, C. A. Soil fertility and electrical conductivity affected by organic waste rates and nutrient inputs. Revista Brasileira de Ciência do Solo, 40:e0150152. 2016.

CORRÊA, J. C. et al. Correção da acidez e modalidade de íons em Latossolo com aplicação superficial de escória, resíduo alcalino, lodo de esgoto e calcário. Pesquisa Agropecuária Brasileira, 42(9):1307-1317, 2007

DALPISOL, M. et al. Zinc, copper and manganese availability in soils treated with alkaline sewage sludge from Paraná state (Brazil). Ciência e Agrotecnologia, 41(1):85-97, 2017.

EMPRESA BRASILEIRA DE PESQUISA AGROPECUÁRIA-EMBRAPA. Manual de métodos de análise de solo. 2. ed. Embrapa Solos: Rio de Janeiro. 2011. 225p.

FINK, J. R et al. Iron oxides and organic matter on soil phosphorus availability. Ciência e Agrotecnologia, 40(4):369-379, 2016. 
GÉRARD F. Clays minerals, iron/aluminum oxides, and their contribution to phosphate sorption in soils - A myth revisited. Geoderma, 262:213-226. 2016.

HEALY, M. G. et al. Metal concentrations in lime stabilized, thermally dried and anaerobically digested sewage sludges. Waste Management, 48:404-408, 2016.

LAL, R. Restoring soil quality to mitigate soil degradation. Sustainability, 7(5):5875-5895, 2015.

LEBLANC, R. J.; MATTHEWS, P.; RICHARD, R. P. Global atlas of excreta, wastewater sludge, and biosolids management: Moving forward the sustainable and welcome uses of a global resource. United Nations Human Settlements Programme (UN-HABITAT), Kenya. 2008. Available in: <http://esa.un.org/iys/docs/san_lib_ docs/habitat2008.pdf>. Access in: February 28, 2017.

MAIO, M. M. et al. Atributos físicos do solo, adubado com lodo de esgoto e silicato de cálcio e magnésio. Ceres, 58(6):823830, 2011.

MARIN, L. M. K. S. et al. Determinação da taxa de aplicação máxima anual de lodo de esgoto higienizado por processo alcalino em solos da região metropolitana de Curitiba. Engenharia Sanitária Ambiental, 15(2):113118,2010

MONDAL, S. et al. Changes in soil quality in response to short-term application of municipal sewage sludge in a Typic Haplustept under cowpea-wheat cropping system. Environmental Nanotechnology, Monitoring and Management, 4:37-41, 2015.

NETO, M. E. et al. Soil chemical attributes of a Dystroferric Red Latosol (Oxisol) treated with an alkaline effluent from a pharmaceutical industry. Semina: Ciências Agrárias, 37(5): 3037-3046, 2016.

NOGUEIROL, R. C.; MONTEIRO, F. A.; AZEVEDO, R. A. Tropical soils cultivated with tomato: Fractionation and speciation of Al. Environmental Monitoring and Assessment, 187(4):160, 2015.

PAVAN, M. A. et al. Manual de análise química de solo. Londrina: Instituto Agronômico do Paraná. 1991. 32p.
PÉRTILE, P. et al. Application of alkaline waste from pulp industry to acid soil with pine. Revista Brasileira de Ciência do Solo, 36(3):939-950, 2012

POGGERE, G. C. et al. Lodos de esgoto alcalinizados em solos do estado do Paraná: Taxa de aplicação máxima anual e comparação entre métodos para recomendação agrícola. Revista Brasileira de Engenharia Agrícola Ambiental. 17:429-438, 2012.

QUINTANA, N. R. G.; BUENO, O. C.; MELO, W. J. Custo de transporte do lodo de esgoto para viabilidade no uso agrícola. Revista Energia na Agricultura, 27(3):90-96, 2012.

RAIJ, B. et al. Interpretação de resultados de análise de solo. In: RAIJ, B. et al. Recomendação de adubação e calagem para o estado de São Paulo. Campinas: Instituto Agronômico de Campinas, 1997. p. 8-13.

RESBURG, H. G. J.; CLAASSENS, A. S.; BEUKES, D. J. Relationships between soil buffer capacity and selected soil properties in a resource-poor farming area in the Mpumalanga Province of South Africa. South African Journal of Plant and Soil, 26(4):237-243, 2009.

ROY, E. D. et al. The phosphorus cost of agricultural intensification in the tropics. Nature Plants, 2(5):16043, 2016.

SERRAT, B. M. et al. Taxa de aplicação máxima anual de lodo de esgoto higienizado pelo processo de estabilização alcalina: Estudo comparativo de curvas de $\mathrm{pH}$ de solos. Revista Brasileira de Ciências Ambientais, 19:30-37, 2011.

SPOSITO, G. The chemistry of soils. Oxford University Press, 2008. 329p.

TAMANINI, C. R. et al. Land reclamation recovery with sewage sludge use. Brazilian Archives of Biology and Technology, 51(4):643-655, 2008.

VENSON, A. H. et al. Acesso aos serviços de abastecimento de água, rede de esgoto e coleta de lixo nos municípios do Paraná: Uma abordagem espacial para os anos de 2006 e 2013. Revista Brasileira de Estudos Regionais e Urbanos, 9(2):243-261, 2015. 